\title{
PERILAKU PENERAPAN PROTOKOL KESEHATAN 3 M PENCEGAHAN COVID-19 PADA IBU HAMIL DI PMB TITIN WIDYANINGSIH TAHUN 2021
}

\author{
Yuliana ${ }^{1},{ }^{2}$ Ummy Yuniantini, ${ }^{3}$ Deviyanti
}

Akademi Kebidanan Panca Bhakti Pontianak

Email korespondensi: yuli.yuliana.uli@gmail.com

\begin{abstract}
Abstrak
Ibu hamil merupakan kelompok risiko tinggi terpapar infeksi virus COVID-19 penurunan kekebalan parsial (sel T). Dampak infeksi virus corona dalam kehamilan dan persalinan yaitu penularan pada bayi (23\%), persalinan SC (59\%), prematur (41\%), kematian ibu (29\%), neonatus (23\%), aborsi spontan (17\%), lahir mati $(17 \%)$, IUFD (17\%), BBLR (17\%), gawat janin (12\%), dan asfiksia neonatal (17\%). Hasil pengamatan peneliti terhadap 7 orang ibu hamil yang berkunjung ke Praktek Mandiri Bidan Titin Widiyaningsih masih ditemukan pelanggaran terhadap penerapan protokol kesehatan 3M.Tujuan penelitian adalah untuk mengetahui perilaku penerapan protokol Kesehatan (3M) ibu hamil di Praktek Mandiri Bidan Titin Widyaningsih Tahun 2021. Metode penelitian adalah deskriptif dengan populasi sebanyak 205 ibu hamil yang memeriksakan kehamilan di Praktek Mandiri Bidan Titin Widyaningsih, dengan jumlah sampel 37 orang dengan menggunakan teknik accidental sampling dan dianalisis univariat. Hasil penelitian menunjukan sebagian besar dari responden 26 orang $(70 \%)$ ibu hamil menggunakan masker selama berkunjung, hampir seluruh responden $36(97 \%)$ tidak mencuci tangan dengan benar dan tepat sesuai anjuran kesehatan, sebagian dari responden $19(51 \%)$ menjaga jarak dengan pengunjung lain selama berkunjung di Praktek Mandiri Bidan Titin Widyaningsih. Sebagian dari responden 21 orang (57\%) tidak melakukan perilaku $3 \mathrm{M}$ yang terdiri dari mencuci tangan, memakai masker dan menjaga jarak selama berkunjung di Praktek Mandiri Bidan Titin Widyaningsih. Saran untuk dibentuknya tim Satgas Covid-19 untuk mengedukasi pengunjung tentang pencegahan Covid-19 dan mengevaluasi penerapan protokol kesehatan 3M di Praktek Mandiri Bidan Titin Widyaningsih.
\end{abstract}

Kata Kunci: Perilaku, Protokol Kesehatan, 3M, Covid-19, Ibu hamil

\begin{abstract}
Pregnant women are a high-risk group for infection with the COVID-19 virus, which reduces partial immunity (T cells). The impact of corona virus infection in pregnancy and childbirth is transmission to infants (23\%), cesarean delivery (59\%), premature (41\%), maternal mortality (29\%), neonates (23\%), spontaneous abortion (17\%), stillbirth (17\%), IUFD (17\%), LBW (17\%), fetal distress (12\%), and neonatal asphyxia (17\%). The results of observations of 7 pregnant women who visited the Independent Practice of Midwife Titin Widiyaningsih still found violations of the application of the $3 M$ health protocol. a population of 205 pregnant women who checked their pregnancies at the Independent Practice of Midwife Titin Widyaningsih, with a sample of 37 people using accidental sampling and univariate analysis. The results showed that most of the respondents 26 people (70\%) pregnant women used masks during their visit, almost all of the respondents 36 (97\%) did not wash their hands properly and appropriately according to health recommendations, some of the respondents 19 (51\%) took care of the visitors. others during a visit to the Independent Practice of Midwife Titin Widyaningsih. some of the 21 respondents (57\%) performed 3 M behaviors that did not consist of washing hands, wearing masks and keeping a distance during a visit to the Independent Practice of Midwife Titin Widyaningsih. Suggestions for the formation of the Covid-19 Task Force team to educate visitors about Covid19 prevention and the application of the $3 M$ health protocol at the Independent Practice of Midwife Titin Widyaningsih.
\end{abstract}

Keywords: Behaviour, Health Protocol, 3 M, Covid-19, Pregnant Women

\footnotetext{
${ }^{1}$ Dosen Akademi Kebidanan Panca Bhakti Pontianak

${ }^{2}$ Dosen Akademi Kebidanan Panca Bhakti Pontianak

${ }^{3}$ Mahasiswa Akademi Kebidanan Panca Bhakti Pontianak
} 


\section{Pendahuluan}

Indonesia merupakan salah satu negara di Asia yang terjangkit pandemi Corona Virus Disease-19 (COVID-19) dengan angka kejadian 179.686.071 terkonfirmasi COVID-19 di Indonesia dan 2.093.962 di Provinsi Kalimantan Barat per tanggal 12 juni 2021 jumlah penderita positif Corona (Covid-19) sebanyak 12.050 orang (Kemenkes RI, 2021). COVID-19 dilaporkan mayoritas menyerang kelompok lanjut usia, namun, belakangan ini dilaporkan juga telah menyerang seluruh kelompok usia (bayi, balita, remaja, usia produktif, dan kelompok ibu hamil). Perkembangan penularan virus ini cukup signifikan karena penyebarannya sudah mendunia dan munculnya varian-varian baru akibat mutasi dari virus corona (Lei et al., 2020).

Ibu hamil merupakan kelompok risiko tinggi terpapar infeksi virus COVID-19 karena perubahan fisiologis pada masa kehamilan mengakibatkan kekebalan parsial (sel T) menurun (Liang \& Acharya, 2020). Hasil penelitian study literatur dari beberapa peneliti menyampaikan dampak COVID-19 pada kehamilan adalah demam (47\%), batuk (47\%), persalinan dengan operasi sesar (59\%), persalinan prematur $(41 \%)$, perawatan wanita hamil secara intensif (29\%), kematian ibu (29\%), kematian neonatus (23\%), neonatus positif COVID-19 (23\%), aborsi spontan (17\%), lahir mati (17\%), kematian intrauterin (17\%), BBLR (17\%), gawat janin (12\%), dan asfiksia neonatal (17\%) (Rumfabe, et.al,
2020).

Pemerintah melalui satuan tugas gugus percepatan penanganan COVID-19 sesuai Keputusan Presiden republik Indonesia Nomor 12 Tahun 2020 mengeluarkan panduan yang berisi himbauan perilaku kesehatan untuk mencegah penularan virus COVID-19 dengan mencuci tangan menggunakan sabun dibawah air mengalir selama 40-60 detik atau menggunakan cairan antiseptik berbasis alkohol (handsanitizer) minimal 20-30 detik atau menggunakan hand sanitizier, food and drug administration (FDA) bahwa hand-sanitizer bisa membunuh kuman dalam waktu kurang dari 30 detik. Menggunakan alat pelindung diri berupa masker yang menutupi hidung dan mulut jika harus keluar rumah atau berinteraksi dengan orang lain yang tidak diketahui status kesehatannya (yang mungkin dapat menularkan COVID-19) agar virus tersebut tidak menginfeksi saluran pernafasan (Kementerian Kesehatan RI, 2020). Menggunakan masker medis lebih disarankan karena efektivitasnya dalam melindungi dari percikan droplet, filter kuman dan menyerap cairan pengguna (Ika, 2020). Menjaga jarak minimal 1 meter dengan orang lain untuk menghindari terkena droplet dari orang yang yang batuk atau bersin, menurut bukti yang ada, SARS-CoV-2 menyebar terutama dari orang ke orang saat orang yang terinfeksi berada dalam jarak kontak erat dengan orang lain (WHO, 2020). 
Praktek Mandiri Bidan Titin Widyaningsih merupakan salah satu tempat esensial yang memberikan pelayanan KIA. Adanya pandemi COVID-19 mengharuskan bidan dan pasien beradaptasi dengan kebiasaan baru. Arahan protokol Kesehatan sudah seharusnya ditaati dan di implementasikan, termasuk pada pelayanan kesehatan di PMB Titin Widyaningsih. Hasil studi pendahuluan yang dilakukan peneliti di ketahui bahwa selama bulan Maret - Mei 2021 jumlah kunjungan ibu hamil sebanyak 205 orang. Berdasarkan hasil pengamatan peneliti terhadap 7 orang ibu hamil yang datang berkunjung ke PMB Titin Widiyaningsih diketahui 2 orang ibu hamil yang tidak memakai masker, 5 orang menggunakan masker namun masih sering melepas masker, 7 orang mencuci tangan hanya sekedar membasahkan tangan, $3 \mathrm{ibu}$

\section{Hasil dan Pembahasan}

Tabel 1.1

"Distribusi frekuensi Penerapan Perilaku Protokol Kesehatan 3M Memakai Masker, Mencuci Tangan, Menjaga Jarak di Praktek Mandiri Bidan Titin Widyaningsih Tahun 2021"

\begin{tabular}{|l|c|c|c|c|c|c|}
\hline \multirow{2}{*}{\begin{tabular}{l} 
PMilaku \\
\cline { 2 - 7 }
\end{tabular}} & \multicolumn{2}{|c|}{ Ya } & \multicolumn{2}{c|}{ Tidak } & \multicolumn{2}{c|}{ Total } \\
\hline $\begin{array}{l}\text { Memakai } \\
\text { masker }\end{array}$ & 26 & 70 & 11 & 30 & 37 & 100 \\
\hline $\begin{array}{l}\text { Mencuci } \\
\text { tangan }\end{array}$ & 1 & 3 & 36 & 97 & 37 & 100 \\
\hline $\begin{array}{l}\text { Manjaga } \\
\text { jarak }\end{array}$ & 19 & 51 & 18 & 49 & 37 & 100 \\
\hline $\begin{array}{l}\text { Perilaku } \\
\text { 3M }\end{array}$ & 16 & 43 & 21 & 57 & 37 & 100 \\
\hline
\end{tabular}

Sumber : data olahan tahun 2021

Berdasarkan tabel 1.1 diatas diketahui sebagian besar dari responden 26 orang (70\%) ibu hamil menggunakan masker saat menjaga jarak saat menunggu pelayanan dari bidan. Berdasarkan latar belakang yang telah diuraikan oleh peneliti dimana perilaku penerapanan protokol kesehatan 3M pada ibu hamil yang berisiko tertularnya Covid-19 yang berkunjung belum baik saat berada di Praktek Bidan Mandiri Titin Widyaningsih, menarik peneliti melakukan penelitian dengan judul "Perilaku Penerapan Protokol Kesehatan (3M) Pencegahan Covid -19 Pada Ibu Hamil Di Praktek Mandiri Bidan Titin Widyaningsih Tahun 2021".

\section{Metode}

Penelitian ini menggunakan metode deskriptif dengan pendekatan cross sectional. Sampel sebanyak 37 ibu hamil yang berkunjung ke Praktik Mandiri Bidan Titin Widyaningsih. Pengumpulan data menggunakan lembar observasi, kemudian diolah dan dianalisis secara univariat menggunakan komputerisasi. berkunjung di Praktek Mandiri Bidan Titin Widyaningsih. Hampir seluruh responden 36 orang $(97 \%)$ ibu hamil tidak mencuci tangan dengan benar sesuai panduan kesehatan. Sebagian dari responden 19 orang (51\%) menjaga jarak selama berkunjung di Praktek Mandiri Bidan Titin Widyaningsih dengan tidak berkerumun, duduk dengan jarak 1-2 meter. Perilaku ibu hamil dalam menerapkan 3M didapatkan hasil bahwa sebagian dari responden 21 orang $(57 \%)$ tidak melakukan perilaku 3M yang terdiri dari mencuci tangan, memakai masker dan menjaga jarak selama berkunjung di Praktek Mandiri Bidan Titin Widyaningsih. 


\section{Pembahasan}

\section{a. Perilaku Ibu Hamil Menggunakan Masker}

Hasil penelitian dengan melakukan observasi terhadap perilaku memakai masker 37 orang ibu hamil di Praktek Mandiri Bidan Titin Widyaningsih Tahun 2021 diketahui bahwa Sebagian besar dari responden 26 orang $(70 \%)$ ibu hamil yang menggunakan masker dan Sebagian kecil dari responden 11 orang (30\%) ibu hamil tidak menerapkan perilaku memakai masker dengan benar sesuai panduan Kesehatan. Perilaku memakai masker dalam penelitian ini sebagian besar dari ibu hamil yang memakai masker saat berada di wilayah Praktek Mandiri Bidan Titin Widyaningsih karena syarat utama untuk masuk ke PMB hanya menggunakan masker saja. Penelitian lain juga melaporkan masih ada masyarakat yang tidak pernah menggunakan masker ketika keluar rumah 1 orang $(0,67 \%)$ (Purnamayanti Made et al., 2020).

Tim Gugus Tugas Nasional Percepatan Penanganan COVID-19 mewajibkan semua orang memakai masker selama masa pandemi COVID-19. Terdapat 3 jenis masker yang dapat digunakan yaitu masker kain, masker bedah, dan masker N95. Masker kain yang direkomendasikan harus memiliki 3 lapisan kain. Lapisan pertama yaitu lapisan kain hidrofilik seperti katun, lapisan kedua menggunakan katun atau polyester dan lapisan ketiga menggunakan lapisan hidrofobik atau bersifat anti-air (polypropylene) (Putsanra, 2020).
Hal ini juga dibuktikan dalam hasil penelitian di Hanoi, Vietnam pada 1.607 rumah sakit yang melaporkan terdapat perbedaan yang sangat signifikan antara penggunaan masker bedah dan masker kain dalam mencegah infeksi saluran pernafasan maupun infeksi virus dimana responden yang menggunakan masker kain 13 kali berisiko menderita infeksi saluran nafas dan infeksi virus dibandingkan dengan yang memakai masker bedah karena penetrasi partikel virus melalui masker kain hampir 97\% dibandingkan masker medis 44\% (Hang et al., 2014).

Menurut peneliti sebagian besar ibu hamil sudah menerapkan perilaku memakai masker dengan benar sesuai panduan Kesehatan yang merupakan syarat utama berkunjung ke PMB selama pandemi sehingga menjadi sorotan utama tenaga Kesehatan dan pengunjung sekitar.

\section{b. Perilaku Ibu Hamil Mencuci Tangan}

Hasil observasi terhadap perilaku mencuci tangan 37 ibu hamil di Praktek Mandiri Bidan Titin Widyaningsih Tahun 2021 diketahui hampir seluruh responden 36 (97\%) ibu hamil tidak mencuci tangan dan sangat sedikit dari responden 1 (3\%) ibu hamil yang mencuci tangan dengan benar sesuai panduan kesehatan dan penyediaan fasilitas sudah memadai.

Perilaku mencuci tangan ibu hamil dalam penelitian ini hanya sebatas membasahi tangan dengan membuka keran air tanpa memberi sabun, selain itu perilaku lain yang ditemui adalah mencuci tangan 
dengan sabun dibawah air mengalir hanya 1-

2 langkah jika ada tenaga kesehatan.

Penggunaan hand sanitizier oleh ibu hamil selama berada di PMB Titin Widyaningsih hampir tidak dimanfaatkan, namun ada ditemukan ibu yang membawa handsanitizier dan sesekali menyemprotkannya selama menunggu antrian pelayanan kesehatan.

Mencuci tangan dengan benar dapat membunuh virus dan kuman yang ada di tangan, jika tidak ada air dan sabun ibu hamil bisa menggunakan hand sanitizer. Hand sanitizer dengan kadar alcohol minimal $60 \%$ cukup efektif untuk membasmi kuman di tangan (BPS, 2020).

Penelitian ini sejalan dengan hasil survey Badan Pusat Statistik yang melaporkan bahwa tingkatan kepatuhan masyarakat untuk mencuci tangan sebagai perilaku pencegahan covid-19 adalah 75,38\% (cuci tangan dengan sabun) dan 21\% (dengan Hand sanitizier) lebih rendah dibandingkan perilaku memakai masker $91,98 \%$, menjaga jarak $73,54 \%$ dan menghindari kerumunan 76,69\% (BPS, 2020).

Faktor penghambat perilaku mencuci tangan di masyarakat dalam survey tersebut disebabkan oleh dampak dari mencuci tangan seperti kaki terkena cipratan air, tangan menjadi basah sehingga harus menyediakan perlengkapan seperti tisu, dan banyaknya hand sanitizer dijual dengan harga relatif murah sehingga terjangkau oleh semua kalangan ekonomi dan lebih praktis untuk diterapkan serta persepsi apabila memakai sabun murah tangan akan menjadi kering, lelah dengan ajuran pemerintah, atau tempat cuci tangan yang tidak kelihatan. Selain itu di tempat-tempat umum seperti mall, rumah sakit memang disediakan fasilitas cuci tangan, namun yang menjadi syarat seseorang bisa masuk adalah menggunakan masker dan suhu tubuh normal, hal ini membuat perilaku mencuci tangan menjadi terabaikan (BPS, 2020).

Menurut peneliti rendahnya perilaku mencuci tangan pada ibu hamil karena perilaku ini bukan syarat utama yang harus dipenuhi klien saat berkunjung ke PMB selain itu tidak adanya petugas khusus yang berada di area cuci tangan membuat ibu hamil melewatkan perilaku protokol kesehatan tersebut.

\section{c. Perilaku Ibu Hamil Menjaga Jarak}

Hasil observasi terhadap perilaku menjaga jarak 37 ibu hamil di PMB Titin Widyaningsih Tahun 2021 diketahui sebagian dari responden 19 (51\%) menjaga jarak dan sebagian dari responden 18 orang (49\%) tidak menjaga jarak.

Ibu hamil yang berkunjung perlu menjaga jarak bertujuan untuk menghindari penyebaran penyakit akibat virus corona, jarak 2 meter dinilai sebagai jarak yang aman agar ibu terhindari dari percikan cairan atau droplet yang dikeluarkan oleh orang yang batuk atau bersin di sekitar ibu (Pradana et al., 2020). Hasil penelitian ini sejalan dengan penelitian lainnya, dimana dari 1.102 responden di Indonesia, mayoritas memiliki sikap yang positif (53\%) dan perilaku yang baik (93\%) terkait penerapan social 
distancing (Purnamayanti Made et al., 2020).

Selain itu, penelitian lain yang dilaksanakan di Provinsi DKI Jakarta juga memberikan hasil yang sejalan dengan penelitian ini yaitu $70,7 \%$ responden memiliki sikap yang baik, dan $70,3 \%$ responden memiliki keterampilan yang baik dalam pencegahan COVID-19 (Utami et al., 2020). Berdasarkan penelitian-penelitian tersebut, maka perilaku seseorang pula menjadi aspek penting yang perlu diperhatikan dalam rangka mencegah dan menangani kasus COVID-19.

\section{d. Perilaku protokol kesehatan 3 M Ibu}

\section{Hamil}

Hasil observasi terhadap perilaku 3M 37 ibu hamil di PMB Titin Widyaningsih Tahun 2021 diketahui bahwa sebagian dari responden 21 orang (57\%) ibu hamil yang tidak melakukan perilaku $3 \mathrm{M}$ memakai masker, mencuci tangan, menjaga jarak dan Sebagian dari responden 16 orang (43\%) ibu hamil melakukan perilaku 3M memakai masker, mencuci tangan, menajaga jarak dengan benar sesuai panduan kesehatan.

Penelitian ini sejalan dengan BKKBN, hasil observasi yang telah dilakukan sebelumnya menunjukkan, sebanyak $65 \%$ pegawai kantor BKKBN pusat tidak menggunakan masker dengan tepat, tidak mencuci tangan dan menjaga jarak. Ada 25\% pegawai mengabaikan penerapan peraturan yang telah dikeluarkan oleh BKKBN pusat dengan fasilitas/saran yang sudah memadai. Dari data-data yang telah didapatkan saat melakukan studi pendahuluan dapat disimpulkan bahwa perilaku pencegahan penularan Covid-19 pada pegawai BKKBN pusat masih tergolong kurang baik (Sari Andesta \& Budiono Irwan, 2021).

Perilaku 3M memakai masker, mencuci tangan, dan menjaga jarak dalam penelitian ini masih ada ibu hamil yg tidak menerapkan perilaku 3M karena syarat utama untuk masuk ke wilayah PMB Titin Widyaningsih hanya menggunakan masker saja sudah bisa masuk tanpa mencuci tangan dan menjaga jarak sesuai dengan panduan kesehatan.

Penelitian ini tidak sejalan dengan penelitian Mujiburrahman dkk, (2020) menunjukkan bahwa sebanyak (43.2\%) masyarakat di Dusun Potorono Banguntapan Bantul D.I. Yogyakarta berperilaku cukup baik. Bentuk perilaku yang ditunjukkan antara lain kepatuhan dalam menjaga jarak saat di luar rumah, selalu mencuci tangan dengan sabun atau hand sanitizer sebelum masuk rumah, toko/minimarket, atm dan fasilitas lainnya, taat menggunakan masker saat berpergian dan tidak bersentuhan atau salaman dengan orang lain (Mujiburrahman, 2020).

Menurut peneliti rendahnya ibu hamil yang tidak melakukan perilaku $3 \mathrm{M}$ sesuai dengan panduan kesehatan, karena kurangnya pengawasan dari pihak PMB Titin Widyaningsih membuat ibu hamil melewatkan perilaku protokol Kesehatan tersebut. Perlunya membentuk tim Satuan Tugas Penanganan Covid-19 di PMB Titin WD diharapkan dapat meningkatkan penerapan perilaku $3 \mathrm{M}$ pada ibu hamil 
sebelum dan selama berkunjung ke PMB.

\section{Kesimpulan}

Sebanyak 21 orang (57\%) ibu hamil menerapkan perilaku $3 \mathrm{M}$, perilaku $3 \mathrm{M}$ ibu hamil paling rendah yaitu mencuci tangan sesuai panduan kesehatan. Perlu adanya edukasi dan pengulangan himbauan perilaku

\section{Daftar Pustaka}

Badan Pusat Statistik. 2020. Survei Sosial Demografi Dampak Covid-19. https://mediaindonesia.com/read/detail/ 320412-survei-perempuan-lebih-baikdalam-penerapan-protokol-kesehatan.

Hang, et.al. 2020. A cluster randomised trial of cloth masks compared with medical masks in healthcare workers. BMJ Open Journal.

https://www.ncbi.nlm.nih.gov/pmc/artic les/PMC4420971/pdf/bmjopen-2014006577.pdf

Ika. 2020. Efektifitas Masker Kain Cegah Covid-19. Universitas Gajahmada https://www.ugm.ac.id/id/berita/19280efektivitas-masker-kain-cegah-covid19-paling-rendah

Kementrian Kesehatan Republik Indonesia. 2020. Pedoman Pencegahan dan Pengendalian Corona virus Disease (Covid-

19).https://www.persi.or.id/images/202 0/data/kmk2472020.

Lei, et.al. 2020. Clinical characteristics and outcomes of patients undergoing surgeries during the incubation period of COVID-19 infection. .Eclinic Medicine. Volume 21. https://doi.org/10.1016/j.eclinm.2020.1 00331

Liang, H, dan Acharya, G. 2020. Novel Corona Virus Disease (Covid-19). Acta Obstetricia et Gynecologica Scandinavica, volume 99 , issue 4 https://munin.uit.no/handle/10037/2092 2
3M yaitu memakai masker, mencuci tangan, menjaga jarak, dengan cara memutar video protokol Kesehatan 3M dengan menambahkan TV diruang tunggu dan memutar himbauan protokol Kesehatan 3M secara konsisten dengan pengeras suara

Pradana, A, dan Nur, A. 2020. Pengaruh Kebijakan Sosial Distancing pada Wabah covid-19 Terhadap Kelompok Rentan di Indonesia. Jurnal Kebijakan Kesehatan Indonesia Volume 09 Nomor 02, Halaman 61-67 https://jurnalihttps://jurnal.ugm.ac.id/jk ki/article/view/55575/27986

Purnamayanti Made et al., 2020. Pengetahuan, Sikap dan Kepatuhan Penggunaan Masker oleh Ibu Hamil pada Masa Pandemi COVID-19 di Kota Denpasar. Jurnal Ilmiah Kebidanan volume 9, issue $1 . \quad \mathrm{https}: / /$ ejournal.poltekkesdenpasar.ac.id/index.php/JIK/article/vie w/1476

Putsanra, 2020. 3 Jenis Masker yang Efektif Cegah Corona COVID-19 Menurut Kemenkes. https://tirto.id/3-jenismasker-yang-efektif-cegah-coronacovid-19-menurut-kemenkes-f5aW

Rumfabe,et.al. 2020. Dampak Coronavirus Disease 2019 (Covid-19) Pada Kehamilan Sejak Desember 2019 Hingga Agustus 2020 Melalui Tinjauan Literatur. Wal'afiat Hospital Journal, Volume 1, Edisi 1. https://whj.umi.ac.id/index.php/whj/arti cle/view/45/16.

Sari, D, dan Atiqoh, N. 2020. Hubungan Antara Pengetahuan Masyarakat Dengan Kepatuhan Penggunaan Masker Sebagai Upaya Pencegahan Penyakit Covid-19 di Ngronggah. Jurnal Ilmiah Rekam Medis dan Informatika Kesehatan. Volume 10, issue 1. https://ojs.udb.ac.id/index.php/infokes/a $\underline{\text { rticle/view/850/755 }}$ 
Utami ,et.al. 2020. Pengetahuan, Sikap dan Keterampilan Masyarakat dalam Pencegahan COVID-19 di DKI Jakarta. Jurnal Kesehatan Holistik, Volume 4, Issue

https://www.researchgate.net/publication/343 307853_Pengetahuan_Sikap_dan_Keter ampilan_Masyarakat_dalam_Pencegaha n_COVID19_di_DKI_Jakarta/link/5f8c 463d92851c14bccf7f86/download
World Health Organization, 2020. Data Global kejadian Infeksi Virus COVID-19 di Dunia. https://covid19.who.int/ 